\title{
SYNTHESIS AND A P P L I C A T IO N OF SILICA GEL BASE ON MOUNT SINABUNG'S FLY ASH FOR Cd(II) REMOVAL WITH FIXED BED COLUMN
}

\author{
Lisnawaty Simatupang ${ }^{1,2}$, Rikson Siburian ${ }^{3 *}$, Parna Sitanggang ${ }^{1}$, Maryati \\ Doloksaribu $^{4}$, Manihar Situmorang ${ }^{1}$ and Harlem Marpaung ${ }^{3}$ \\ ${ }^{1}$ Department of Chemistry- Faculty of Mathematics and Natural Sciences Universitas \\ Negeri Medan Jl. Willem Iskandar Psr. V, Medan 20221, Indonesia \\ ${ }^{2}$ Postgraduated Chemistry Department-Faculty of Mathematics and Natural Sciences \\ Universitas Sumatera Utara, Medan 20155, Indonesia \\ ${ }^{3}$ Chemistry Department-Faculty of Mathematics and Natural Sciences Universitas \\ Sumatera Utara, Medan 20155, Indonesia \\ ${ }^{4}$ Physic Department-Faculty of Mathematics and Natural Sciences Universitas Negeri \\ Medan Jl. Willem Iskandar Psr. V, Medan 20221, Indonesia \\ *E-mail: riksonsiburian2000@yahoo.com
}

\begin{abstract}
Synthesis of silica gel base on Mount Sinabung's volcanic ash taken from different villages, was carried out. The purposes of this research are to synthesis and characterized by silica gel which was generated base on ash. The method of this research is a sol-gel method. The silica gel w as characterized by Fourier Transform Infra Red (FTIR), X-Ray Diffraction (XRD), and Barret Emmet Teller (BET) respectively. The silica gel consists of $\mathrm{Si}-\mathrm{O}-\mathrm{Si}$ and $\mathrm{Si}-\mathrm{OH}$ groups. XRD data also shows that silica is amorphous. BET data show that the surface area of silica gel is $374.994 \mathrm{~m}^{2} / \mathrm{g}$. A fix bed Column of silica gel was used for the removal of Cd(II). The adsorption column used has a diameter of $1.7 \mathrm{~cm}$ and is filled with $0.5 \mathrm{~g}$ of silica. the optimum adsorption capacity is: flow rate $4 \mathrm{~mL} / \mathrm{min}(21,194 \mathrm{mg} / \mathrm{g})$. The initial optimum concentration is $24 \mathrm{ppm}(21.632 \mathrm{mg} /$ $\mathrm{g})$. The optimum $\mathrm{pH}$ is $\mathrm{pH} 6,(21.848 \mathrm{mg} / \mathrm{g})$. The experiment result showed silica adsorbent effective for removal Cadmium
\end{abstract}

Keywords: Silica volcanic ash of Sinabung,adsorption, cadmium, fixed bed column.

@ $\operatorname{RASĀYAN.~All~rights~reserved~}$

\section{INTRODUCTION}

Sinabung's mountain is one of the active volcanoes which is located in North Sumatra provinceIndonesia. Its coordinates are $03^{\circ} 10^{\prime} \mathrm{LU}$ dan $98^{\circ} 23^{\prime} \mathrm{BT}$ with the highest peak of 2,460 meters above sea level. This mountain is very interesting due to it has erupted since 2010 until now ${ }^{1}$. It is constantly erupting and expelling millions of cubic volcanic ash materials. The abundance of mountain volcanic ash material as a result of the eruption of Mount Sinabung is an interesting thing to be studied and utilized further.

Several studies have shown that volcanic ash volcanoes contain mainly silica material ${ }^{2}$. Zuarida reported that amount silica oxide $\left(\mathrm{SiO}_{2}\right)$ on Kelud volcanic mountain's ash is $45.9 \%^{3}$, Merapi volcanic mountain's ash is $56.39 \%^{4}$, Sinabung volcanic mountain's ash is $58,10 \%$ and $74.3 \%{ }^{6}$. It means the ash is Sinabung mountain's higher than others and very potential as a raw material to produce adsorbent base on silica.

Silica is a giant molecule and usage as an adsorbent. It is possible because its large pore and have both silanol group (-Si-OH) and siloksan (-Si-O-Si-) as an active site. There are four oxygen atoms on $\mathrm{Si}$; it may be used as an active site to bind metal namely chemical bonding between $\mathrm{Si}-\mathrm{Metal}^{7}$. 
The fast growth of the various industry caused increase waste and contributes the pollution of aquatic environment ${ }^{8,9}$. Heavy metals are known to have high toxicity and carsinogenic which tends to affect the lives of humans and other living beings. This is because heavy metals are very difficult and furthermore they are resistant to bacteria or decomposition processes which result in excessive accumulation of concentrations in the aquatic environment exposed by heavy metals continuously ${ }^{10-14}$. Cadmium is one of the most toxic and harmful metals. This is dangerous for humans because in relatively small quantities can lead to death in poisoned creatures. This is due to the biological systems of the human body, these metal are non-essential . Industrial activities involving cadmium use include textile industry, battery manufacture, metal coating, paint / color ink, printing, agrochemicals etc. ${ }^{12-14}$

Most about studies adsorption process of heavy metals using adsorbents as rice husk ash ${ }^{12,19-21}$,fly ash $^{13,17-18}$, coal fly ash ${ }^{15-16}$, peat and mollusk ${ }^{14}$, activated carbon ${ }^{10}$, moringa oleifera bark ${ }^{11}$ have been done. The adsorption process about used of adsorbents such as rice husk ash, fly ash, peat and mollusk shell, chitin ${ }^{22}$, algae ${ }^{23}$ have been widely used in the release of Cadmium in both wastewater and aqueous solution using fixed bed column studied is report ${ }^{12-14}$. But the use of volcanic ash as an adsorbent to removal Cadmium has not been used. There are only a few studies that have used volcanic ash as an adsorbent ${ }^{24-25}$. Base on recent situation the main objective of this research was to determine the adsorption capacity of silica gel from volcanic ash Sinabung as an adsorbent to removal cadmium from aqueous solution by fixed bed column method including flow rate, $\mathrm{pH}$, and concentration of Cadmium.

\section{EXPERIMENTAL}

The volcanic ash was taken from four villages at Kecamatan Simpang Empat- Karo District, those are Desa Beras Tepu, Sigarang-garang, Kuta Gunggung, and Kuta Rakyat. The villages distance is around 3, 4, 5 and $6 \mathrm{Km}$ to the top side of Sinabung Mountain. Then, it was brought to research laboratory of Chemistry Department- University of State-Medan. Subsequently, it calls as a sample.

\section{Characterization of Volcanic Ash}

The sample was sieved to generate the homogenized sample (200 mesh). After that, the sample was characterized with XRF.

\section{Synthesis of Silica}

20 gram of volcanic ash was soaked into $120 \mathrm{~mL} \mathrm{HNO} 3$ for 24 hours. Then, it was dried on the oven at $\mathrm{T}=120^{\circ} \mathrm{C}$ and 6 hours and its weight were recorded. Subsequently, the volcanic ash was destructed with $156 \mathrm{~mL} \mathrm{NaOH} 4 \mathrm{M}$ until the viscous at the furnace. It will be carried out at 500 ${ }^{\circ} \mathrm{C}$ and 30 minutes. After that, it was added $200 \mathrm{~mL}$ water for 24 hours.Finally, the solution was filtered and characterized by using AAS. It is denoted as Na-Silicat $\left(\mathrm{Na}_{2} \mathrm{SiO}_{3}\right)$

\section{Synthesis of Silica Gel}

$20 \mathrm{~mL}$ Na-Silica solution was put into porcelain. $\mathrm{HCl} 3 \mathrm{M}$ was gradually dropped on Na-Silica and stirred until the white gel was formed and $\mathrm{pH}$ gel was neutral. Then, silica gel was filtered and rinsed with water until its $\mathrm{pH}$ was neutral. Finally, silica gel was dried into the oven under conditions $\mathrm{T}=120{ }^{\circ} \mathrm{C}$ for 6 hours. Silica gel was characterized by using AAS, FTIR, XRD and Surface Area Analyzer, respectively.

\section{Fixed Column Adsorption Studies of Cd(II)}

Silica gel that had synthesized used as adsorbent using fixed column method. The column that was used has the diameter of $1.7 \mathrm{~cm}$ and the amount of silica used in each study was 0.5 grams. The respective concentration of $\mathrm{Cd}$ (II) solution flowed through the column with the respective amount flow rate and $\mathrm{pH}$ value. The effluent solution then collected every 15 minutes and the concentration was measured to calculate the adsorption capacity of each study to determine the optimal amount of flow rate, initial concentration, and $\mathrm{pH}$ value of column adsorption. 


\section{Formation of Silica Gel}

\section{RESULTS AND DISCUSSION}

The gray smooth powder of volcanic ash was characterized by XRF analysis to examine the main components of Sinabung volcanic ash. The result shows Si content is $91.4 \%$, then was converted as $\mathrm{SiO}_{2}$ content of volcanic ash is $42.65 \%{ }^{26}$.It indicates the volcanic ash has a cement pozzolant material with high $\mathrm{SiO}_{2}$ concentrate. Formation of silica gel is started by reacting between volcanic ash and $\mathrm{NaOH} 4 \mathrm{M}$ at $\mathrm{T}=500{ }^{\circ} \mathrm{C}$. Sodium hydroxide is dissociated at that temperature to form sodium and hydroxide ions. At $\mathrm{SiO}_{2}$, electro negativity of oxygen is higher than silica ( $\mathrm{Si}$ ), so

$\mathrm{Si}$ is much more electropositive and forms intermediate $\left[\mathrm{SiO}_{2} \mathrm{OH}\right]^{-}$which it is unstable and dehydrogenation occur. Ion $\mathrm{Na}^{+}$will react with $\mathrm{SiO}_{3}{ }^{2-}$ to form sodium silica $\left(\mathrm{Na}_{2} \mathrm{SiO}_{3}\right)$. The mechanism reaction is shown in Fig. $-1^{27}$.

Table-1: Composition of Sinabung Mountain's Volcanic Ash

\begin{tabular}{c|c}
\hline Volcanic ash components & Amount $(\%)$ \\
\hline $\mathrm{Si}$ & $91.4 \pm 0.1$ \\
\hline $\mathrm{K}$ & $3.09 \pm 0.02$ \\
\hline $\mathrm{Ca}$ & $2.60 \pm 0.02$ \\
\hline $\mathrm{Cr}$ & $0.086 \pm 0.003$ \\
\hline $\mathrm{Mn}$ & $0.19 \pm 0.03$ \\
\hline $\mathrm{Fe}$ & $0.54 \pm 0.01$ \\
\hline $\mathrm{Ni}$ & $1.09 \pm 0.02$ \\
\hline $\mathrm{Cu}$ & $0.18 \pm 0.003$ \\
\hline $\mathrm{Zn}$ & $0.32 \pm 0.01$ \\
\hline $\mathrm{Ga}$ & $0.090 \pm 0.003$ \\
\hline $\mathrm{Eu}$ & $0.2 \pm 0.02$ \\
\hline $\mathrm{Re}$ & $0.3 \pm 0.03$ \\
\hline &
\end{tabular}

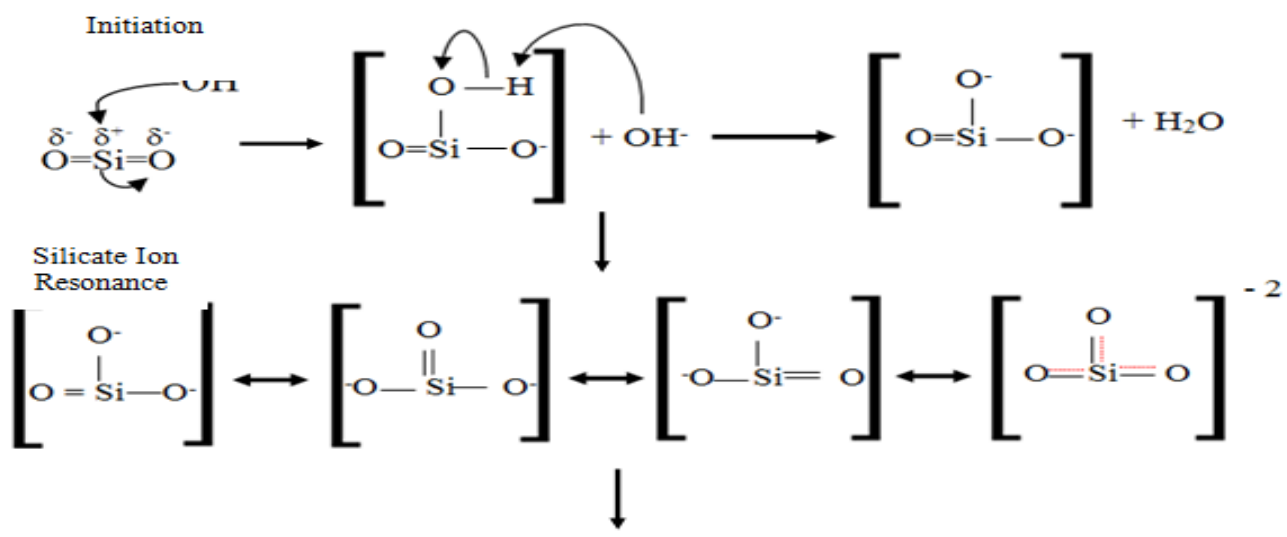

Final Phase

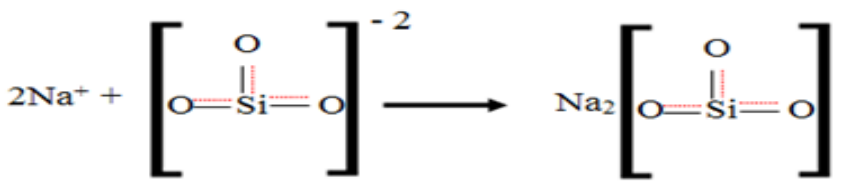

Fig.-1: Mechanism reaction of Sodium Silicate formation

Silica gel was formed by using sol-gel preparation method using hydrochloric acid. When, hydrochloric acid was added, it caused ionic exchange between $\mathrm{H}^{+}$and $\mathrm{Na}^{+}$to form silicic acid which did not dissolve in the solution. ${ }^{28}$ The formation of silica precipitates was observed at $\mathrm{pH}$ 
14 , however, the gel precipitates started to form at $\mathrm{pH} 8$ to 10 . And the addition of hydrochloric acid was stopped at $\mathrm{pH} 7$. In the formation of silica gel, the silicic acid which formed from the reaction between hydrochloric acid and sodium silicate solution exhibited water polycondensation to form dimers, trimers, and polymers of silicic acid thus releasing water polycondensation to form dimers, trimers, and polymers of silicic acid thus releasing water molecule in the process. ${ }^{29}$

\section{Silicic Acid Formation}

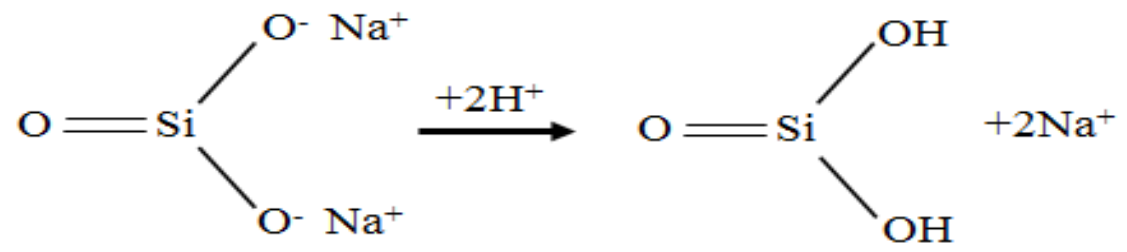

\section{FTIR Analysis}

Fig.-2: Mechanism Reaction of Silicic Acid Formation

Silica gel also was characterized by using FTIR. FTIR data is shown in Fig.- 4. The broad peak of $3433.29 \mathrm{~cm}^{-1}$ is a specific peak for hydroxyl functional group $(-\mathrm{OH})$. Normally, $-\mathrm{OH}$ group should appear at $3500 \mathrm{~cm}^{-1}$. It means there is an interaction between electropositive substances and $-\mathrm{OH}$, namely Si-OH (2862.36 and $\left.2927.94 \mathrm{~cm}^{-1}\right)$. Therefore, the peak shifts to the lower wave length number. Thereby, the type silica of volcanic ash is probably Si-OH or Si-O-Si. In addition, the sharp and broad peak at $1095.57 \mathrm{~cm}^{-1}$ also indicates Si-O-Si is there. That is also supported by appearing peak at $466.77 \mathrm{~cm}^{-1}, 798.53 \mathrm{~cm}^{-1}$ and $2357.01 \mathrm{~cm}^{-1}$ as well as Si-O-Si

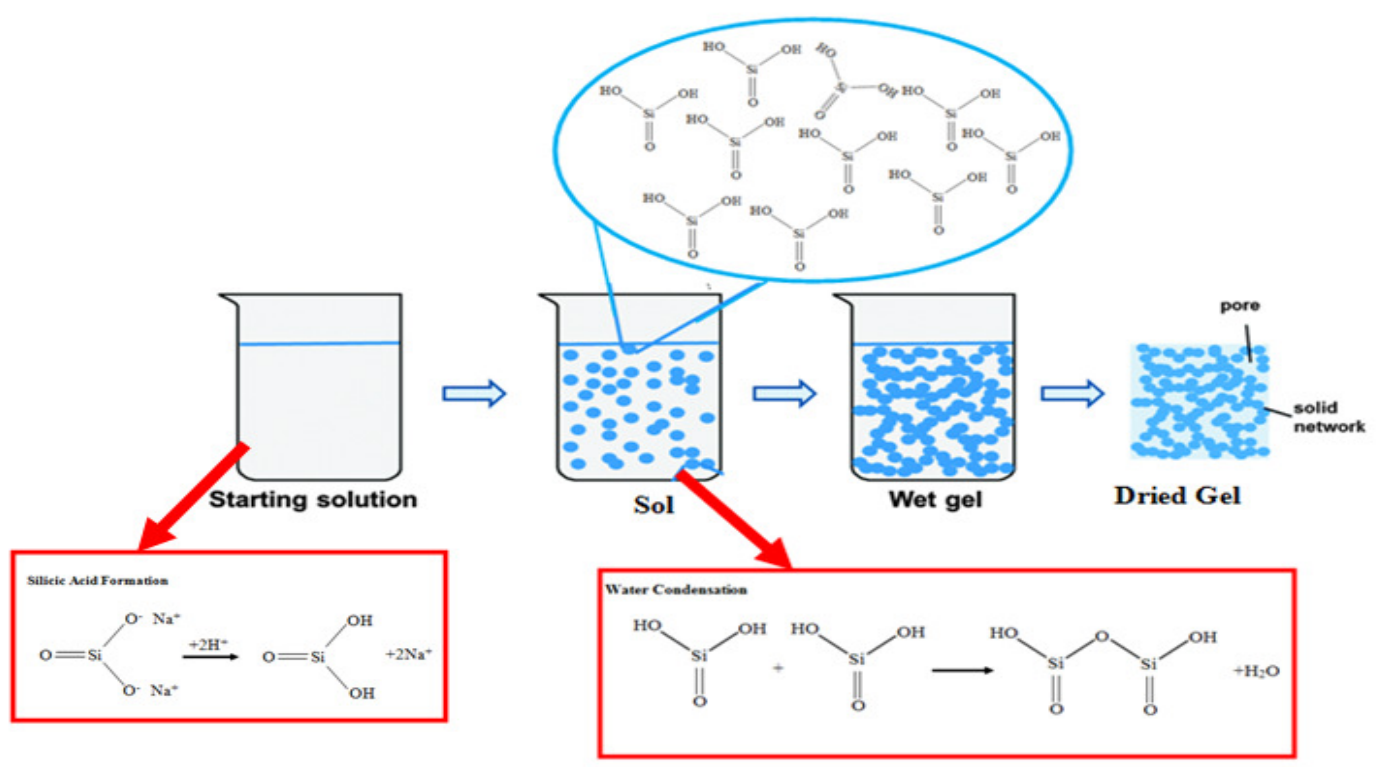

\section{XRD Studies}

Fig.-3: Mechanism of Sol-Gel Reaction

XRD curve for the prepared of Silica gel from different villages with sol-gel methods is showing in Fig.-5. 
XRD patterns show broad peaks at $2 \theta=20-24^{\circ}$. It indicates silica that the XRD data of volcanic ash from Kuta Rakyat, Kuta Gunggung, Sigarang-Garang, Beras Tepu is shown the $2 \theta$ number of Beras Tepu is lowest among the others $(2 \theta=21.8800)$ with a diameter $(\mathrm{d})=4.05889 \AA$ $(0.4059 \mathrm{~nm})$. On the other hand, $2 \theta$ number of Kuta Rakyat is highest among the others $2 \theta=$ 24.2600 with $d=3.66582 \AA(0.3665 \mathrm{~nm})$. XRD data also shows that the silica is amorphous which it is possible to be applied as adsorbent ${ }^{29}$.

\section{Analysis of BET}

Characterization of silica surface area is characterized by BET aims to determine the pore radius and surface area of silica gel. Base on XRD data, silica gel of Beras Tepu is so special due to crystal and the $2 \theta$ number. Therefore, the BET number is determined. Figure- 6 presents the nitrogen adsorption/desorption isotherms measured for the silica.

The results showed that the average pore radius of $1,5469 \times 10^{-1} \AA$, pore volume total of $2,900 \times 10^{-1}$ $\mathrm{ml} / \mathrm{g}$ for pores smaller than $1387.4 \AA$ (Radius), surface area $374,994 \mathrm{~m}^{2} / \mathrm{g}$. Base on The International Union of Pure and Applied Chemistry (IUPAC) that the silica gel is micropore ${ }^{30}$. Compared with previous research, the synthesis of silica gel from sands of southern Tunisia, which is specific surface area exceeded $340 \mathrm{~m}^{2} / \mathrm{g}^{31}$ is much wider, so it is suitable for use as an adsorbent in the adsorption process.

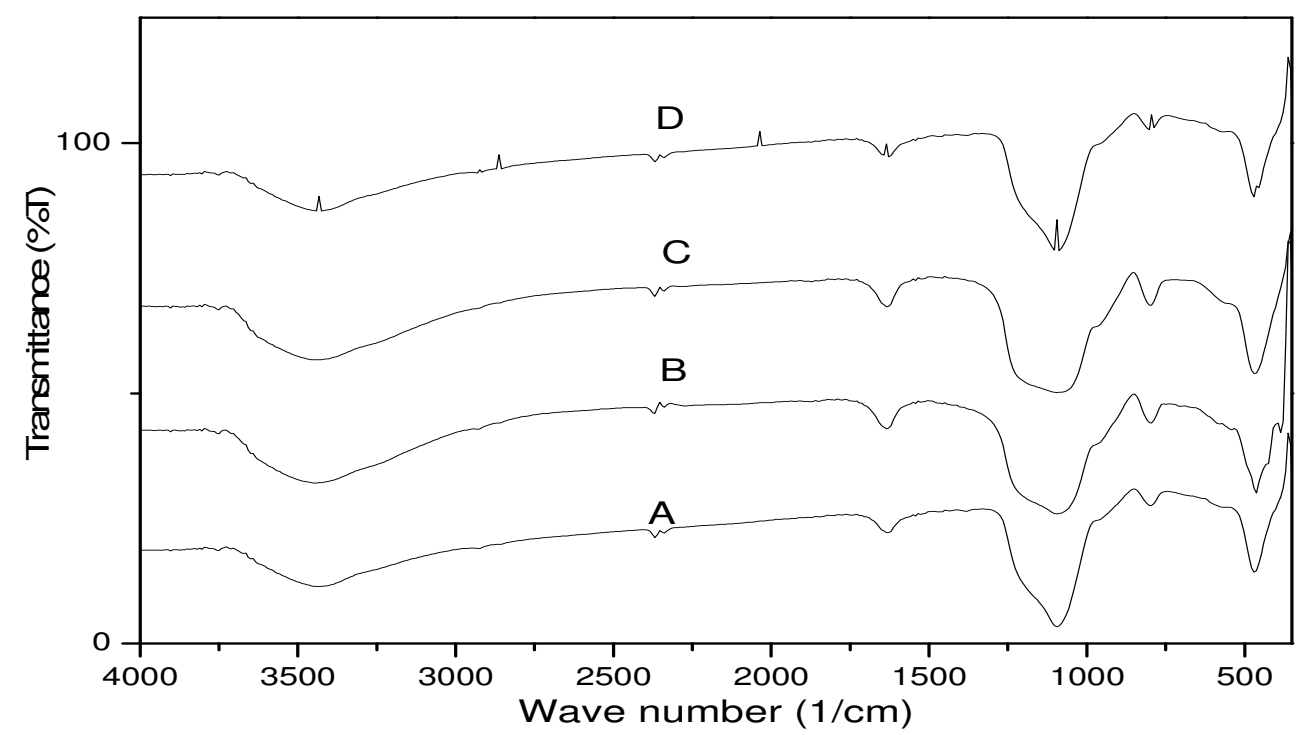

Fig.-4: FTIR Spektra of Silica from A.Kuta Rakyat, B. Kuta gunggung, C. Sigarang-garang, D. Beras Tepu

\section{Fixed Column Adsorption Studies of Cd(II) Effect of Influent Flow Rate}

An adsorption study was carried to determine the optimal flow rate of $\mathrm{Cd}(\mathrm{II})$ adsorbate in the column adsorption. The flow rates variations were $3 \mathrm{~mL} / \mathrm{min}, 4 \mathrm{~mL} / \mathrm{min}$, and $5 \mathrm{~mL} / \mathrm{min}$. The adsorbate concentration used was $24 \mathrm{mg} / \mathrm{L}$ and the $\mathrm{pH}$ of influent was adjusted to 5 . The experimental parameter is described in Table-2. In order to determine the optimal influent flow rate, the breakthrough point and the adsorption capacity of each column study are calculated. The breakthrough point of each column study is shown in Fig.-7.

The result shows that the adsorption capacity of $\mathrm{Cd}(\mathrm{II})$ is increasing flow rate $3 \mathrm{~mL} / \mathrm{min}$ to flow rate $4 \mathrm{~mL} / \mathrm{min}$ then decreases in flow rate $5 \mathrm{~mL} / \mathrm{min}$. An increase in flow rate reduces the metal ion solution treated efficiently until a breakthrough point and therefore decrease the contact time between the metal ion and the silica gel. When the flow rate decreases, the contact time in the column is longer, pore diffusion then becomes effective. Thus metal ions have more time to diffuse to the porous of silica column and the better adsorption capacity is obtained ${ }^{32}$. However, the 
increasing adsorption capacity from flow rate $3 \mathrm{~mL} / \mathrm{min}$ to $4 \mathrm{~mL} / \mathrm{min}$ is happened due to the optimal effect of silica gel, where from experiment the optimal adsorption capacity obtained is at flow rate $4 \mathrm{~mL} / \mathrm{min}$.

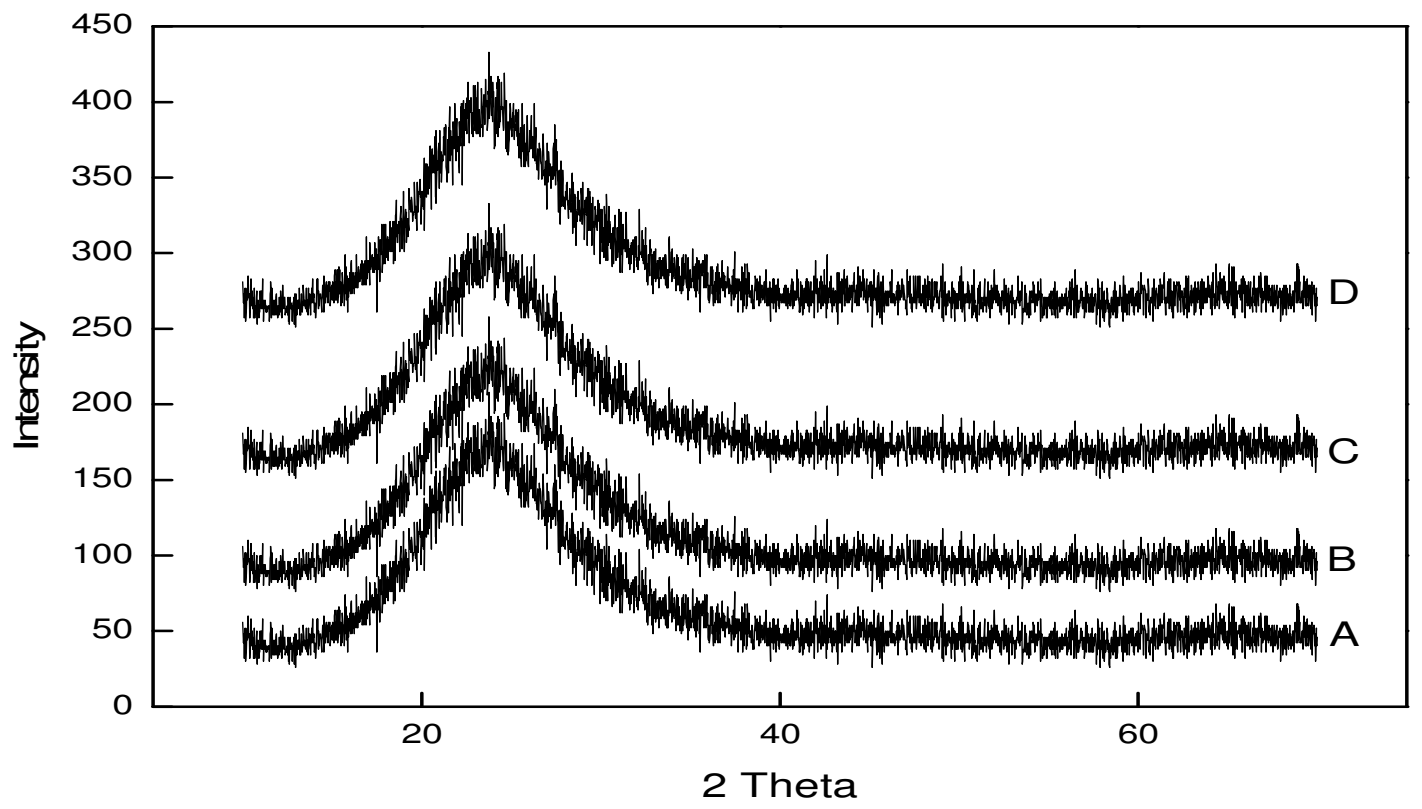

Fig.- 5: XRD imange of Silica from A.Kuta Rakyat, B. Kuta gunggung, C. Sigarang-garang, D. Beras Tepu

Table-2. The experimental Parameter of Adsorption Study Using Different Flow Rate

\begin{tabular}{l|c|c|c}
\hline \multirow{2}{*}{\multicolumn{1}{c|}{ Experimental parameters }} & \multicolumn{3}{c}{ Fixed Bed Column Adsorption Experimental } \\
\cline { 2 - 4 } & Experiment 1 & Experiment 2 & Experiment 3 \\
\hline Influent Flow Rate (mL/min) & 3.00 & 4.00 & 5.00 \\
\hline Influent Cadmium Concentration (mg/L) & 24.00 & 24.00 & 24.00 \\
\hline Silica Gel (g) & 0.50 & 0.50 & 0.50 \\
\hline pH of Influent Solution & 5.00 & 5.00 & 5.00 \\
\hline Service Time (min) & 180 & 180 & 180 \\
\hline Total Cadmium Solution Treated (L) & 0.54 & 0.72 & 0.90 \\
\hline Total Cadmium Adsorbed (mg) & 9.879 & 10.690 & 9.806 \\
\hline Adsorption Capacity (mg/g) & 19.759 & 21.380 & 19.612 \\
\hline
\end{tabular}

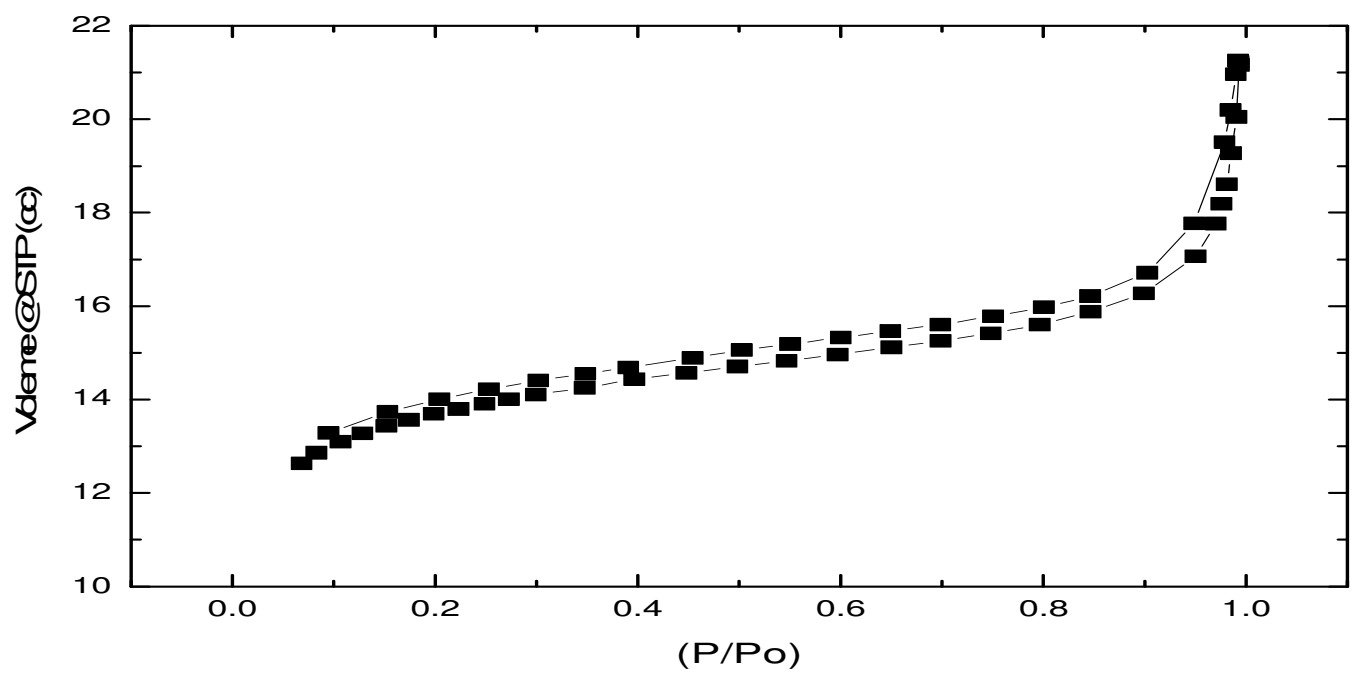

Fig.- 6: Isotherms Data Measured at 77.350K 
Table-3: Experimental Parameter of Adsorption Study Using Different Initial Concentration

\begin{tabular}{l|c|c|c}
\hline \multirow{2}{*}{\multicolumn{1}{c|}{ Experimental parameters }} & \multicolumn{3}{c}{ Fixed Bed Column Adsorption Experimental } \\
\cline { 2 - 4 } & Experiment 1 & Experiment 2 & Experiment 3 \\
\hline Influent Flow Rate $(\mathrm{mL} / \mathrm{min})$ & 4.00 & 4.00 & 4.00 \\
\hline Influent Cadmium Concentration $(\mathrm{mg} / \mathrm{L})$ & 20.00 & 24.00 & 30.00 \\
\hline Silica Gel $(\mathrm{g})$ & 0.50 & 0.50 & 0.50 \\
\hline $\mathrm{pH}$ of Influent Solution & 5.00 & 5.00 & 5.00 \\
\hline Service Time (min) & 180 & 180 & 180 \\
\hline Total Cadmium Solution Treated (L) & 0.72 & 0.72 & 0.72 \\
\hline Total Cadmium Adsorbed (mg) & 10.116 & 10.815 & 9.718 \\
\hline Adsorption Capacity (mg/g) & 20.232 & 21.631 & 19.437 \\
\hline
\end{tabular}

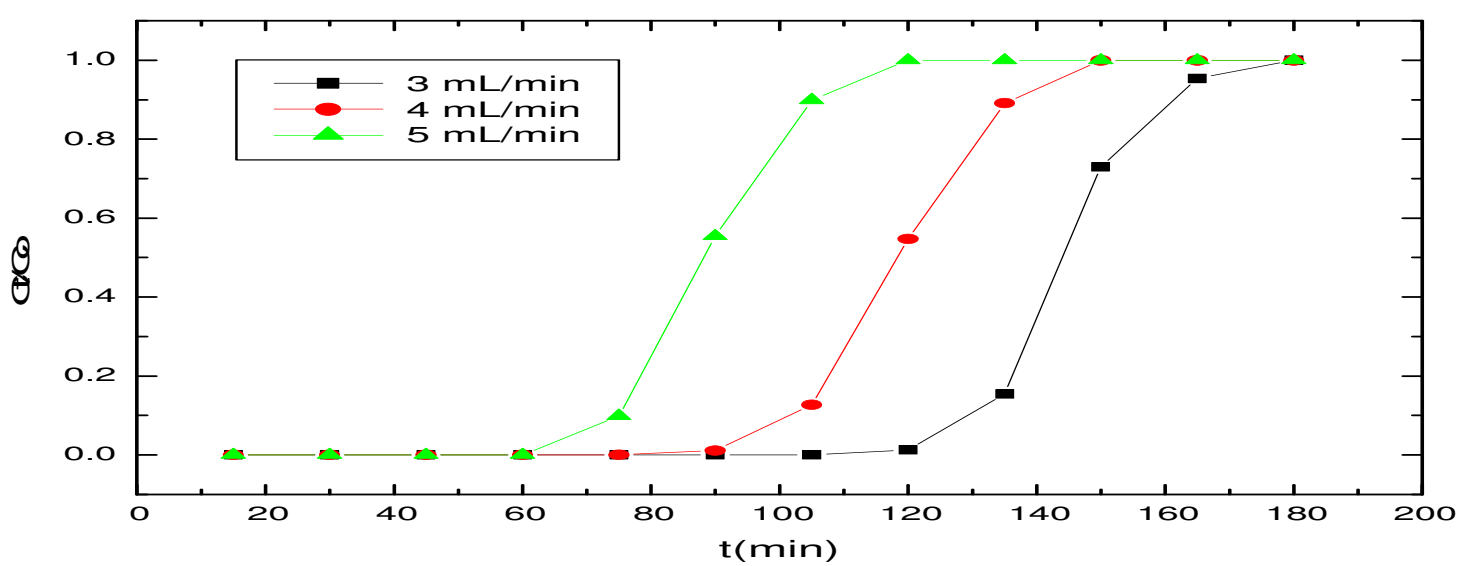

Fig.-7: Breakthrough Curves for Cadmium(II) Adsorption by Silica for a Different Flow Rate of, 3, 4 and 5

\section{Effect of Initial Influent Concentration}

$\mathrm{mL} / \mathrm{min}$

The optimal flow rate of $4 \mathrm{~mL} / \mathrm{min}$ which obtained from the first study was used in this study. Where the initial concentrations used were $20 \mathrm{mg} / \mathrm{L}, 24 \mathrm{mg} / \mathrm{L}$, and $30 \mathrm{mg} / \mathrm{L}$. The $\mathrm{pH}$ of influent was adjusted to 5. The experimental parameter is described in table 3 and The breakthrough point of each column study is shown in Fig.-8.

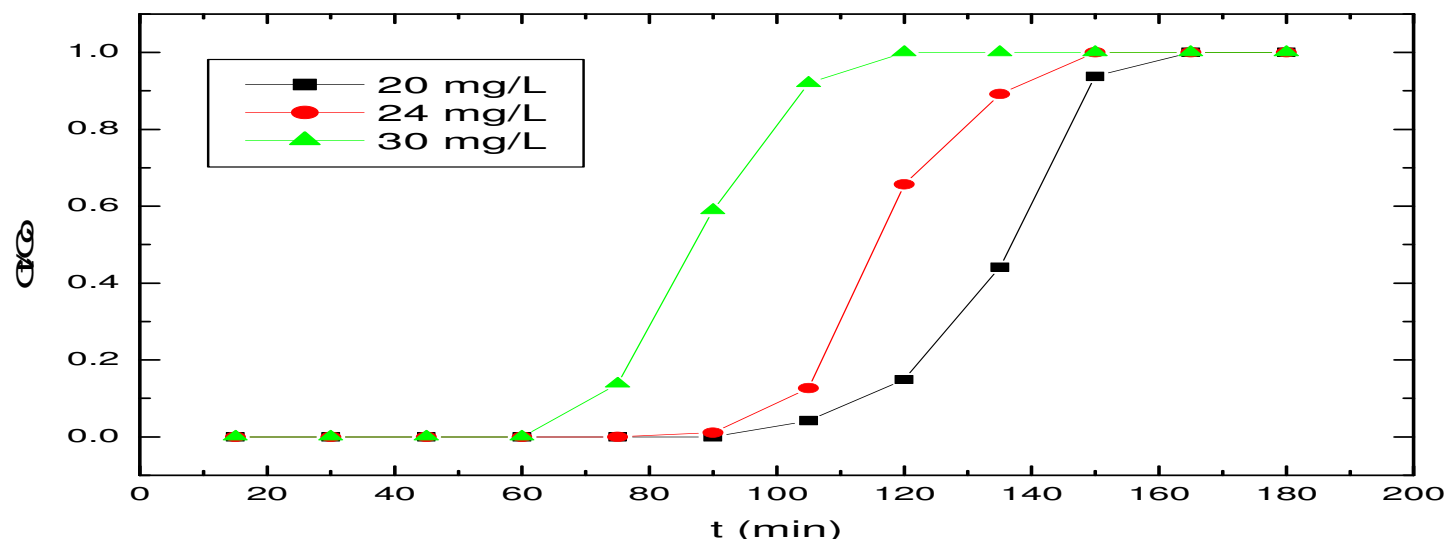

Fig.-8: Breakthrough Curves of Cd(II) Removal by Silica for the Different Initial Concentration of 20,24 and $30 \mathrm{mg} / \mathrm{L}$

The result shows that the highest adsorption capacity is at initial influent concentration $24 \mathrm{mg} / \mathrm{L}$. The amount of initial influent concentration effects the adsorption capacity of metal ion, where the increasing of initial concentration causing the saturation of adsorbent porous more quickly. When the saturation has occurred on the adsorbent layer, the further contact with metal ion would cause 
two conditions. The first condition is the formation of another layer, thus creating the multilayer adsorption. And the other condition where the adsorbed metal ion escapes from adsorbent porous and diffuses back to the solution. The adsorption of $\mathrm{Cd}(\mathrm{II})$ ions by silica gel follows the second condition, where the increasing initial influent concentration which higher than the optimal concentration will cause a drop in adsorption capacity.

Table-4: Experimental Parameter of Adsorption Study using Different $\mathrm{pH}$

\begin{tabular}{l|c|c|c}
\hline \multirow{2}{*}{\multicolumn{1}{c|}{ Experimental parameters }} & \multicolumn{3}{c}{ Fixed Bed Column Adsorption Experimental } \\
\cline { 2 - 4 } & Experiment 1 & Experiment 2 & Experiment 3 \\
\hline Influent Flow Rate (mL/min) & 4.00 & 4.00 & 4.00 \\
\hline Influent Cadmium Concentration (mg/L) & 24.00 & 24.00 & 24.00 \\
\hline Silica Gel (g) & 0.50 & 0.50 & 0.50 \\
\hline pH of Influent Solution & 5.00 & 6.00 & 7.00 \\
\hline Service Time (min) & 180 & 180 & 180 \\
\hline Total Cadmium Solution Treated (L) & 0.72 & 0.72 & 0.72 \\
\hline Total Cadmium Adsorbed (mg) & 10.840 & 10.924 & 10.478 \\
\hline Adsorption Capacity (mg/g) & 21.681 & 21.848 & 20.957 \\
\hline
\end{tabular}

Effect of Influent pH Value

These studies were carried out to determine the optimal $\mathrm{pH}$ value of $\mathrm{Cd}(\mathrm{II})$ ions adsorption. Where the optimal flow rate of $4 \mathrm{~mL} / \mathrm{min}$ and the optimal initial influent concentration of $24 \mathrm{mg} / \mathrm{L}$ are used in this study. The $\mathrm{pH}$ values used are 5, 6, and 7. The experimental parameter is described in table 4 and the breakthrough point of each study is shown in Fig.-9.

According to the data shown that were no significant differences adsorption capacity between ffluent $\mathrm{pH} 5,6,7$. The result showed that the highest amount of adsorption capacity was observed at $\mathrm{pH} 6$. The adsorptive ability of an adsorbent is influence by the $\mathrm{pH}$ of adsorbate. This is because the protonation and deprotonation of the active site of the adsorbent ${ }^{34}$. In the low $\mathrm{pH}$ surface acid conditions the adsorbent is also positively charged, cause a repulsion between the adsorbent surface and the metal ion, resulting in low adsorption. However at $\mathrm{pH} \mathrm{7,} \mathrm{The} \mathrm{presence} \mathrm{of} \mathrm{OH}$ ions in aqueous solution causes the interaction between $\mathrm{Cd}$ and $\mathrm{OH}$ - to result deposit cadmium hydroxide $\mathrm{Cd}(\mathrm{OH})_{2}$ so that the adsorption capacity becomes decreased ${ }^{34}$.

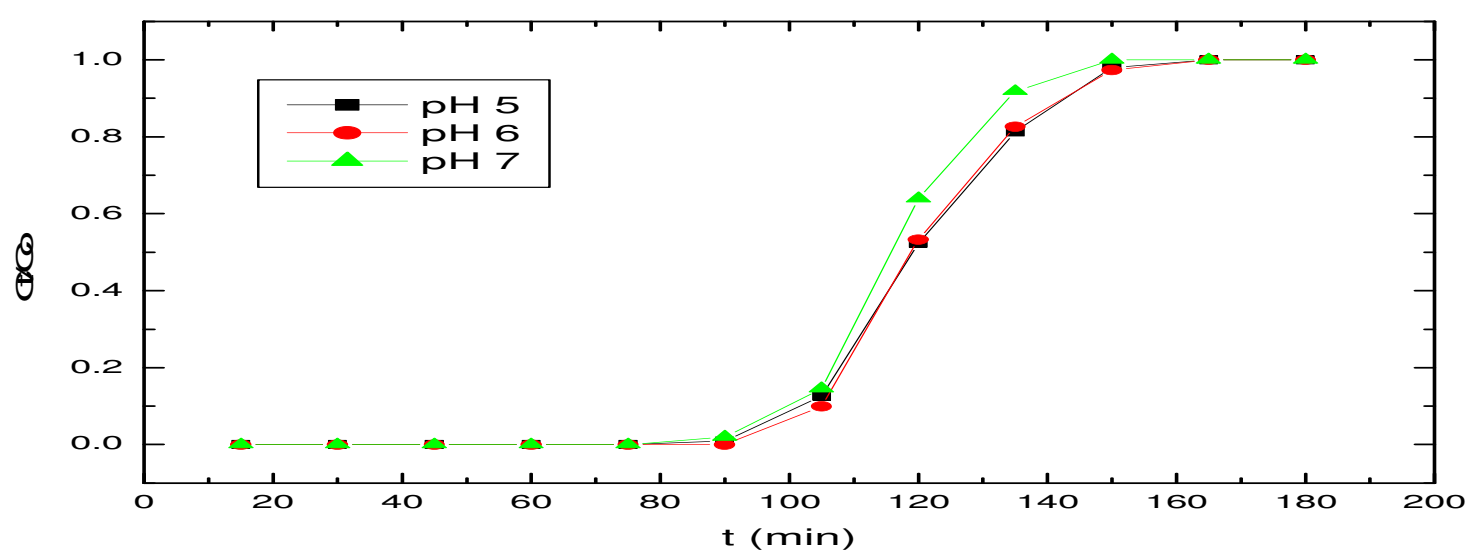

Fig.-9: Breakthrough Curves for Cadmium (II) Adsorption by Silica for Different pH 5,6,7

\section{CONCLUSION}

The silica gel is well synthesized by using volcanic ash base on Sinabung Mountain. The silica gel consists of $-\mathrm{OH}$ from $\mathrm{Si}-\mathrm{OH}$ and $\mathrm{Si}-\mathrm{O}$ from $\mathrm{Si}-\mathrm{O}-\mathrm{Si}$. The silica gel is well generated on this research is amorphous, average pore radius of $1,5469 \times 10^{-1} \AA$, the surface area of silica gel is $374.994 \mathrm{~m}^{2} / \mathrm{g}$ which it is possible to be applied as an adsorbent. The optimum adsorption capacity of silica gel to metal ion of $\mathrm{Cd}$ (II) with fixed bed column method is: Flow rate $4 \mathrm{~mL} / \mathrm{min}$ with metal ion 
adsorption capacity of Cd (II) equal to $21,194 \mathrm{mg} / \mathrm{g}$. The initial optimum concentration was 24 ppm with an adsorption capacity of $21.632 \mathrm{mg} / \mathrm{g}$. The optimum $\mathrm{pH}$ is $\mathrm{pH}$ 6, wherein the adsorption capacity of Cd (II) metal ions is $21.848 \mathrm{mg} / \mathrm{g}$.

\section{REFERENCES}

1. I.S.Sutawidjaja, O. Prambada, DA Siregar, Indonesian Journal of Geology, 8, 55(2013).

2. I. Kusmartini, W. Y. N. Syahfitri, S. Kurniawati, D. D. Lestiani, M. Santoso , Journal of Physics: Conf. Series, 860 (2017), DOI:10.1088/1742-6596/860/1/012005

3. Zuraida, Thesis, Department of Land, Institut Pertanian Bogor, Bogor, Indonesia (1999)

4. M. Anda, M. Sarwani, Soil Science Society of America Journal, 76,733(2012)

5. http://www.eri.u-tokyo.ac.jp/en/2014/02/04/eruptive-activity-of-sinabung-volcano-in-2013-and2014/

6. R. Karolina, Syahrizal, M. A.Putra, T. A. Prasetyo, Procedia Engineering, 125, 669(2015).

7. G.F. Brinker and G. W. Scherer, The Physics and Chemistry of Sol Gel Processing, Academic Press, San Diego, California, p. 620-622 (1990)

8. S. Tamilselvi and M. Asaithambi, Rasayan J. Chem, 8(1), 84(2015)

9. Y.A.B. Neolaka, E.B.S Kalla, G.A. Malelak, N.K. Rukman, G. Supriyanto, N.N.T. Puspaningsih, Rasayan J. Chem., 11 (2), 494 (2018), DOI :10.7324/RJC.2018.1121994

10. K. Velumani, P.E. Kumar, V. Sivakumar, Rasayan J. Chem, 9(2), 149 (2016)

11. V. H. Waghmare and U. E. Chaudhari, Rasayan J. Chem., 7( 3), 214(2014)

12. U. Kumar and . Bandyopadhyay, Journal of Hazardous Materials B, 129,253(2006)

13. B. Thakur, A. K. Misra, M. Biswas, K. Bandyopadhyay, J. Inst. Eng. India Ser. A, 94(3), 161(2013), DOI : 10.1007/s40030-014-0054-2

14. C.Li, P.Champagne, Journal of Hazardous Materials, 171, 872(2009), DOI: 10.1016/j.jhazmat.2009.06.084

15. A. Papandreou, C.J. Stournaras, D. Panias, J. Hazard. Mater. B, 148, 538(2007)

16. S. Mohan, R. Gandhimathi, J. Hazard. Mater., 169, 351(2009)

17. M. Visa, C. Bogatu, A. Duta, Appl. Surf. Sci., 256(17), 5486(2010)

18. M. Visa, R.A. Carcel, L. Andronic, A. Duta, Catal. Today, 144(1-2), 137(2009)

19. L. Simatupang, R.S. Dewi, B. Sidabutar, Jurnal Pendidikan Kimia, 6(3), 20(2014)

20. M. G. A. Vieira,et.al., Brazilian Journal of Chemical Engineering ,31(2),519(2014), DOI: 10.1590/0104-6632.20140312s00002103

21. A. G. El-Said et al., J Environ Anal Toxicol, 8, 1 (2018), DOI: 10.4172/2161-0525.1000543

22. I. Anastopoulos, A. Bhatnagar, D. N. Bikiaris, and G. Z. Kyzas, Int. J. Mol. Sci., 18(1), 114(2017), DOI : 10.3390/ijms1801011

23. G. Babu Rao, M. Krishna Prasad, K. Kishore Kumar, Ch.V.R.Murthy, Rasayan J. Chem, 9(3) 373-(2016)

24. S. Babel, E. M. Opiso, Int. J. Environ. Sci. Tech., 4 (1), 99(2007)

25. L.Simatupang, D.P.Octavia, M. Doloksaribu, Jurnal Pendidikan Kimia, 9(2), 330(2017)

26. L. Simatupang, D. P. Octavia, Jurnal Pendidikan Kimia, 8(3), 9(2016)

27. L.Trivana, S. Sugiarti, E. Rohaeti, Jurnal Sains dan Teknologi Lingkungan, 7(2), 66(2015)

28. H. Mori, Journal of the Ceramic Society of Japan, 111(6), 376(2003)

29. U.Kalapathy, A.Proctor, J.,A.Shultz, Bioresource Technology, 73, 257(2000)

30. T. M. Budnyak, L.V .Pylypchuk, V. A. Tertykh, E.S. Yanovska, and D. Kolodynska, Nanoscale Research Letters, 10, 87(2015), DOI: 10.1186/s11671-014-0722-1

31. A. Sdiri, T. Higashi, S. Bouaziz, M. Benzina, Arabian Journal of Chemistry, 7, 486(2014)

32. L. Uzun, D.Turkmen, E.Yilmaz, S. Bektas, A.Denizli, Colloids and Surfaces A: Physicochem. Eng. Aspects ,330, 161(2008)

33. Nuryono, V.V.H.Susanti, Narsito, Indo. J. Chem., 3, 32(2003)

34. Sembiring, Z., Buhani, Suharso, Surnadi, Indo. J. Chem., 9(1), 1(2009)

[RJC-2091/2018] 